J. Management and Humanity Research

Vol. 4, 2020, 35-47

ISSN: 2582-7766 (online)

Published on 25 January 2021

www.researchmathsci.org

DOI: http://dx.doi.org/10.22457/jmhr.v04a04404

Journal of

\title{
Public-Private Partnerships in Bangladesh Garment Industries: From the Perspective of Performance Improvement and Sustainability
}

\author{
Tonusree Majumdar \\ School of Management, University of Dhaka, Dhaka, 1000, China. \\ Email: Majumdar88@gmail.com
}

Received 1December 2020; accepted 15 January 2021

\begin{abstract}
Bangladesh has been witnessing tremendous industrial growth across its industrial sector. Textile and apparel have especially dragged the focus of government and private sector. So if public and private sector can make a good relationship according to the public private partnership in Bangladesh Garments Industry it can make a lot of improvement in this industry. Vast availability of lowest manpower, one of the most competitive energy costs and a proven track record in apparel production and exports have positioned Bangladesh as a regional apparel industry development hub in the Asian continent. In context of fast increase in labor wages and raw material prices in other major regional counterparts, such as China, India, Thailand etc., Bangladesh is well poised to remain most preferred destination for international apparel majors for sourcing world class fabric and finished clothes. This paper will reveal some cooperative strategies and implement method for public and private partnership by doing SWOT analysis in Bangladesh Garments Industry. This paper is also devised to find out some strategic way of implementing the Public-Private Partnership (PPP) projects from the perspective of performance improvement and sustainability in Bangladesh Garments Industry.
\end{abstract}

Keywords: PPP (Public-Private partnerships); Formation of PPP; SWOT (strength, weakness, opportunity, threat) analysis; Policy Suggestion.

\section{Introduction}

Today, public-private partnerships are considered as a creative alliances formed between a government entity and private sectors to achieve a common purpose. A project under PPP may include all stages of the project's lifecycle, starting from ideation, design, construction of infrastructure, where necessary and up to delivery of services and maintenance. In such projects, the private sector is the active party which undertakes activities, depending on the model, starting from the stage of conception and up to the stage of operation and maintenance. In most of the cases, PPP allows private sector into areas of business where the government traditionally exerted control (e.g., infrastructure and related services). In a PPP, the public sector retains a significant role, either as the sole purchaser of the services or as the main enabler of the project. The private party 


\section{Tonusree Majumdar}

commonly provides the detailed design, construction, operation, and financing for the PPP project, and is paid according to the performance (Briones, 2012). A partnership is a process not a product. Successful navigation through the process results in net benefits for all parties. Public sector entities can leverage and maximize public assets, increase their control over the development process, and create a vibrant built environment. In an increasingly competitive global environment, governments around the world are focusing on new ways to finance projects, build infrastructure and deliver services. Public-private partnerships (PPP's or P3's) are becoming a common tool to bring together the strengths of both sectors. In addition to maximizing efficiencies and innovations of private enterprise, PPP's can provide much needed capital to finance government programs and projects, thereby freeing public funds for core economic and social programs.

In this thesis, the scope PPP in the garment sector of Bangladesh is investigated as Bangladesh is a developing country and Garments Industry is a big source to foreign currencies. Most of the industries are using PPPs to build and expand their business. Bangladesh Garments Industry has a long-term goal to substitute the China and become the top manufacturer. In order to achieve this goal, both the private and public companies in garment industry have to improve their performance. The GOB (Government of Bangladesh) has taken a two-pronged strategy for building public-private partnership: the first is to attract investment for projects, where building new infrastructure and expanding existing infrastructure is the major component; the second is to attract innovation and sustainability of public service delivery to the citizens. The choice of the PPP arrangement for a Bangladesh garments industry project will depend on its social and economic importance and potential value for money to be generated under such an arrangement. PPP is expected to foster economic growth by developing new commercial opportunities and increasing competition in the provision of public services, thus encouraging private investment.

Bangladesh garments industry involves various stakeholders covering from public, private and international organizations. Ministry of Labor and Employment and its sub-ordinate offices, Ministry of Home Affairs and various law enforcing agencies, political leaders of central and local government, local administration comprise the public side whereas factory owners, managers, officers, garment workers, BGMEA (Bangladesh Garment Manufacturers and Exporters Association), workers' association, member of civil society organizations, NGO activists fall in private sector. In the analytical framework, public private cooperation has been taken as dependent variables whereas investigating the incidents of maintaining law and order situation, bridging gap between the owners and workers and involving the representatives of work-force in the decision-making process have been taken as independent variables. If public and private sectors can work together in Bangladesh Garments Industry the performance of garments industry will reach in very high level. Public-Private Cooperation is an agreement between government and private for bringing together social priorities with the managerial skill of private sector, relieving government of the burden of large capital expenditure, and transferring the cost overruns to the private sector. The success rate of public-private cooperation is high in western world. It is relatively new in Bangladesh and other South Asian countries. For the successful implementation of PPP in the RMG sector of Bangladesh, the level of trust, communication and co-operation between public and private sectors needs to be enhanced. 
Public-Private Partnerships in Bangladesh Garment Industries: From the Perspective of Performance Improvement and Sustainability

\section{Literature review}

A concise historic background of PPP can be found in Grimsey and Lewis $(2004,2005)$. The first public-private cooperation sets were concessions. Mixed public-private ownership is rather a novel concept. Linder (1999) presents taxonomy of public-private partnerships. Schaeffer and Loveridge (2002) review the literature regarding types of public-private cooperation. They conclude that there are "important philosophical and legal differences between private sector and public sector organizations. However, it is exactly because of the differences between the public and the private sector that opportunities for mutually beneficial cooperation arise. The two sectors have complementary powers and thus, each can help the other accomplish things that may otherwise not be feasible".

Gómez-Ibáñez and Meyer (1993) found that Countries worldwide with PPP experience include Australia, Germany, Hungary, Italy, Japan, Korea, Spain, the USA, and the UK. Between 1985 and 2004, there were a total of 2,096 PPP projects worldwide with a total capital value of nearly US $\$ 887$ billion(Conulst,2004).

The trend started in the 1970s as British governments sporadically sought private funding in infrastructure sector. However, the practice of private participation got a firm basis in 1992 when the Conservative government of John Major in the UK first took Private Finance Initiative (PFI). The journey got a momentum when the subsequent Labor government of Tony Blair also embraced the idea with due importance. Afterwards, countries all over the world greeted the concept and now that it has found its implications. Britain has used this Public-Private Partnership (PPP) concept in building schools, hospitals, capital projects like channel tunnel rail link, national air traffic services, improving the London underground, and for defense contracts. During 2003 and 2004, the UK was the country with the largest PPP investments (OECD, 2006). But PublicPrivate Partnership (PPP) conveys a different meaning in Canada. In Canadian context, it relates to the provision of public services or infrastructure and necessitates the transfer of risk between partners. In Bangladesh, it all started from February 15-17, 2008, while there had been a three day conference in Dhaka jointly arranged by the Build-Operate-Transfer Group (BOT Group) of the United Nations Economic Commission of Europe and the Board of Investment (BOI) of the Government of Bangladesh. However, the first ever public-private business forum in Bangladesh was formed on September 06, 2007 in the form of "Bangladesh Better Business Forum" (BBBF), predominantly designed to improve interaction between the business-community and the government high-ups. It is an unparalleled organizational tool for partnership between public and private sectors in Bangladesh. But Bangladesh is not the only one in this part of the globe to introduce Public-Private Partnership (PPP). Neighbors like India, Cambodia, Vietnam, and the Philippines have already undertaken this program in developing infrastructure, tourism, energy and have started reaping its outputs (Hassan,2012).

\subsection{Definition of PPP}

The term "public-private partnership" describes a range of possible relationships among public and private entities in the context of infrastructure and other services. Other terms used for this type of activity include private sector participation (PSP) and privatization. While the three terms have often been used interchangeably, there are differences: 


\section{Tonusree Majumdar}

PPPs present a framework that - while engaging the private sector - acknowledge and structure the role for government in ensuring that social obligations are met and successful sector reforms and public investments achieved.

A strong PPP allocates the tasks, obligations, and risks among the public and private partners in an optimal way. The public partners in a PPP are government entities, including ministries, departments, municipalities, or state-owned enterprises. The private partners can be local or international and may include businesses or investors with technical or financial expertise relevant to the project. Increasingly, PPPs may also include nongovernment organizations (NGOs) and/or community-based organizations (CBOs) who represent stakeholders directly affected by the project. Effective PPPs recognize that the public and the private sectors each have certain advantages, relative to the other, in performing specific tasks. The government's contribution to a PPP may take the form of capital for investment (available through tax revenue), a transfer of assets, or other commitments or in-kind contributions that support the partnership.

The government also provides social responsibility, environmental awareness, local knowledge, and an ability to mobilize political support. The private sector's role in the partnership is to make use of its expertise in commerce, management, operations, and innovation to run the business efficiently. The private partner may also contribute investment capital depending on the form of contract. The structure of the partnership should be designed to allocate risks to the partners who are best able to manage those risks and thus minimize costs while improving performance.

Privatization involves the sale of shares or ownership in a company or the sale of operating assets or services owned by the public sector. Privatization is most common and more widely accepted in sectors that are not traditionally considered public services, such as manufacturing, construction, etc. When privatization occurs in the infrastructure or utilities sectors, it is usually accompanied by sector-specific regulatory arrangements to take account of social and policy concerns related to the sale, and continuing operation of assets used for public services.

\subsection{PPP as a catalyst for broader sector reform}

Governments sometimes see PPP as a catalyst to provoke the larger discussion of and commitment to a sector reform agenda, of which PPPs are only one component. A key issue is always the restructuring and clarifying of roles within a sector. Specifically, there is a requirement to reexamine and reallocate the roles of policy maker, regulator, and service provider, particularly to mobilize capital and achieve efficiency, as outlined above. A reform program that includes PPP provides an opportunity to reconsider the assignment of sector roles to remove any potential conflicts and to consider a private entity as a possible sector participant. Implementing a specific PPP transaction often forces concrete reform steps to support the new allocation of sector roles such as the passage of laws and establishment of separate regulatory bodies. In essence, re-examination of the regulatory and policy arrangements is critical to the success of a PPP project.

\subsection{Advantages of PPPs}

One of the main advantages of the PPP approach is that it can save resources in many ways. The government can concentrate on its core competencies, and does not need to rely on its own resources for unfamiliar projects(Cumming,2007).Because of the 
Public-Private Partnerships in Bangladesh Garment Industries: From the Perspective of Performance Improvement and Sustainability

participation of the private sector, government assets, data and intellectual property can also be utilized more productively, which leads to substantial improvement in the quality of public facilities and services. On the other hand, by proper use of the private sector's skills, experience, technology and innovation, public services can be delivered more satisfactorily. A further advantage is that the public and private sectors can share risks at different stages. As the private sector brings commercial disciplines into public projects, the risk of cost overruns and project delays can be drastically reduced. To finish the design, build, and operation stages with PPP, the private sector can help to make a leaner civil service structure with a more efficient hierarchy of responsibility for services delivery. Other than the advantages for saving resources and more efficient use of them, the economic aspect can be improved by using the PPP approach. For example, it has been showed that PPP leads to the reduction of lifecycle costs, since these projects spread government capital investment over the life of a project. This guarantees the expected rate of return for governmental investment. Although PPP is perceived as a way of creating public infrastructure at little or no cost to the public purse, it is still the notion that "there is no free lunch" is true. Kumaraswamy and Zhang (2001) presented several cases of BOT ventures that had run into problems due to cost overruns, unrealistic price and income projections, and legal disputes between private operators and the government. In virtually all the cases, the government and the general public, but not the private operators, have ultimately shouldered the cost of failure. Their research led us to focus on the point of view from the public sector about the failure of PPP performance. Practitioners have indicated that political obstacles stand in the way of using PPPs. This view is not surprising since PPP projects always need special legislation. In most circumstances, the municipal or state legislature has to discuss this issue at length before legislation is enacted to regulate the use of PPPs.

\section{The development strategy of garment industry -An SWOT analysis}

SWOT is a strategic planning method used to evaluate the Strengths, Weaknesses, Opportunities, and Threats involved in a project, organization, or in a business venture. Strengths are aspects or characteristics of the business, or project teams that give it an advantage over others; Weaknesses are aspects or characteristics that place the organization at a disadvantage relative to others; Opportunities are internal and external prospects that can improve organization's performance within the context; Threats are internal and external influencing factors in the environment that could cause trouble for the function or project.

\subsection{Strengths of private and public companies}

On research we found that the cost of labor is one of the key factors for Bangladesh's success as the average wage per hour of garment factory workers in Bangladesh is only 40US cents. Whereas the per hour wage is $\$ 1.66$ in China,56cents in Pakistan, 51 cents in India, 44 cents in Indonesia, 36 cents Vietnam and higher than this in Europe. The industrial people pointed out that customs dealings and terminal handling have improved here considerably in recent times. Growing number of yarn manufacturing units, the World Bank pointed out that there has been satisfactory growth in backward linkage textile industries here and another strength is that the GSP facility up to 2015 to the 


\section{Tonusree Majumdar}

European Union countries as well. The main fact is that, due to the manpower engaged to carry out the day to day business are all highly skilled, purely professional, vastly experienced. The exclusive combination of organized managerial and technical with government support.

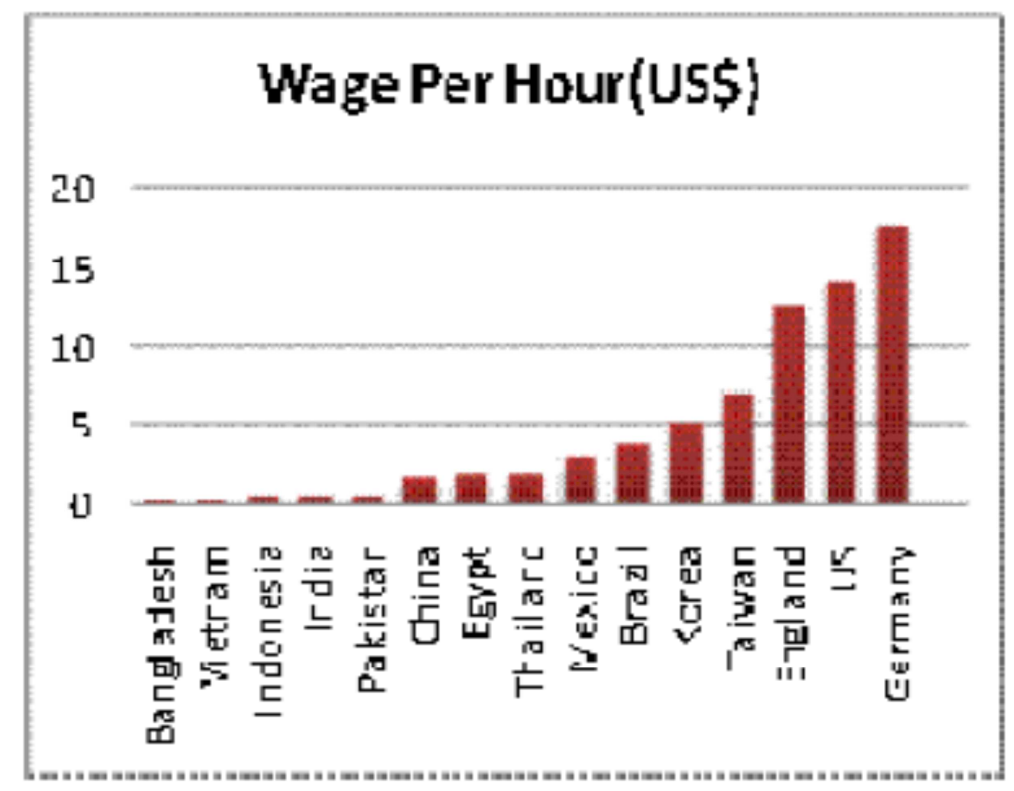

Figure 1: Wage per hour chart of garments factory workers around the world (Source: Bangladesh Textile Today).

\subsection{Weakness of private and public companies}

Lower cost competitiveness has hampered ability to compete with lower cost global players. Labor force in Bangladesh has a much lower productivity as compared to competing countries like China, India, and Sri Lanka etc. Cost like indirect taxes and interest are relatively high. Bangladesh has a history of labor problems. Absence of research and development (R\&D) in the sector is a very big issue. Researchers from the World Bank piercing out that Bangladesh's weakness were lack of good designers and related technology. There is Shortage of skilled workers and worker's unrest, mid-level management people, was pointed out as another drawback. Inefficient infrastructure, lack of industrial expertise, outdated social standards and unavailability of raw materials were also mentioned as the major disadvantages of Bangladesh's terry industry. Technology obsolescence has resulted in the need for significant technology investments to achieve world class quality golf towel and terry towel as well. The financial problems faced by most textile mills in the state. On the other hand Bangladesh does not produce the basic raw materials (only a negligible quantity of cotton but no manufactured fiber) and as such has to depend totally on sensitive global market which is sometimes resulting in insufficient investments in technology so that inadequate backward linkage, lead-time happens to be long, nearly 3 months. Bank interest rate is still high enough, particularly of private sector bank, for investment of export oriented high value project. Still 
Public-Private Partnerships in Bangladesh Garment Industries: From the Perspective of Performance Improvement and Sustainability

Bangladesh is now the world's 6th largest terry exporting country, the entrepreneurs here need to invest in new technology to improve productivity and to reinforce relationships with buyers.

\subsection{Opportunities of Bangladesh garments industry}

The greatest opportunities lie on the unlimited market outside Bangladesh. In a quota free world, the United Nations Commission for Trade and Development estimated that removal of the MFA and tariffs by developed countries will expand exports of clothing by 135 percent and textile by 78 percent. Trela and Whalley using a global general equilibrium model, estimated that the change will be much larger: the value of imports of textiles and clothing will rise by 305 percent in the US, 200 percent in Canada, and 190 percent in EU. This indicates that phasing out of quota will expand the market tremendously. Asia by far is the largest player in the world textile and clothing market and, industry experts are confident that, overall, Asia still will dominate.

Although Bangladesh lags behind in the textile sub-sector, it is very likely that the sector will get a boost through forward integration with RMG. In the knitting sector, Bangladesh gained substantial competitive advantage over her competitors. According to the Bangladeshi Knitwear Management and Exporters Association (BKMEA), the cost of yarn production per $\mathrm{kg}$. In the private sector of Bangladesh is only US\$1.48, whereas in India it is $\$ 1.78$, in Pakistan $\$ 1.60$, in Japan $\$ 2.38$, in Korea $\$ 1.73$ and in Thailand \$2.78 (IFC 1998 cited in Bhattacharya 1999). Therefore, knit-RMG has a good prospect for Bangladesh in post MFA period.

The apparel sector of Bangladesh mainly exports low-cost products to the international market. But she can move into high value added products through diversification. This is not impossible given her two decades of experience, good relationship with buyers, worldwide reputation, and presence in quality-conscious United States and EU markets. Recently it has already penetrated the difficult but lucrative quality-conscious Japanese market.

Due to global consumption is increasing everyday and Bangladesh has some core competency which cannot be achievable by the competing countries, the country should have been acquiring a lion share of the global market. Bangladesh could have achieved such a price competency which would be impossible for others with the help of further increase of productivity, quality and design support. Bangladesh's towel manufacturing sector saw investments of more than Tk 1,000 crore in the last three years, with new entrants coming in to export high-quality products. A number of factories [towel] have come up with big investments. These factories produce high-end items. Shabab Fabrics invested around Tk 250 crore, particularly with the view to export its superior-quality terry towel products. The company has recently installed a production line that can produce 28 tons of towel products a day. Noman Group, a famous readymade garment manufacturer, is another one of the newcomers, who invested around Tk 150 crore for a towel factory. Meanwhile, ACS Textile has invested more than Tk 100 crore to produce high-end terry towels. Polytex and Bismillah Towel, too, undertook further investments to expand their production capacity. Towel manufacturing in Bangladesh, until recently, has been the domain of Pakistani producers, with the first Bangladeshi-owned towel factory being set up in Chittagong in 1984. Presently, around 100 factories, mostly by 


\section{Tonusree Majumdar}

Bangladeshis, are manufacturing and exporting towels, with towel exports fetching $\$ 140$ million in fiscal 2013-14.

As far as we are concerned good signs are floating while we see textile education and research is spreading where Bangladesh, as a proven experienced terry manufacturer, can expand share in the existing market (USA, Australia, EU, Canada etc.) and can also explore opportunity in Japan \& CIS countries. In the future, Bangladesh has a scope to target huge populated country like China and India- where demand as well as cost of manufacturing will be wider. The government gives 5 percent incentive for towel exports to traditional markets such as Europe, Canada and the US, and 10 percent for the non-traditional markets.

\subsection{Threats of Bangladesh garments industry}

India \& Pakistan biggest threat for Bangladeshi RMG \& textile export. The threat also will be the fierce competition from efficient producers like Hong Kong, China, Thailand, and Sri Lanka, Vietnam and many SSA and Caribbean countries. Threats might come not only from marketing but also from outsourcing. As mentioned earlier, more than 95 percent fabrics are imported from direct competitors. The potential danger after 2005 is that these countries might either stop selling their raw materials to Bangladesh or increase the price of their materials tremendously. Whatever may be the case, Bangladesh will lose some competitive edge in the world market. Environmental issues, labor standard, Trade Related Aspects of Intellectual Property Rights (TRIPs) etc. might also appear as a deadly threat to developing countries like Bangladesh.

Although developing countries are not being singled out for environmental issues, being poorer, they cannot obviously maintain rigorous environmental standards. Moreover, the fact that their competitive advantage often lies in natural resources and pollution-intensive industries implies that they are vulnerable to being pressured to enforce stricter standards or face less market access for their exports to developed countries.

Other issues like child labor have already proved as a sensitive issue in the western market. Compliance to the Rules of Origin (ROO) may threaten the future market access and performance of RMG sector of Bangladesh. In the case of woven-RMG, a two-stage, and in the case of knit-RMG, a three-stage transformation (cotton to yarn, yarn to fabrics, and fabrics to RMG) process is required for imported yarn from India. Bangladesh exporters also had to pay back exempted duties amounting to about US\$60 million (as per an agreement in October 1997) to $\mathrm{EU}$ on the grounds of ROO violation and circumvention (Bhattacharya 1999).

Regionalism is another threat to the industry. The World Bank country study (1995) expresses its concerns that "Over the medium term it is also possible that NAFTA may lead to a displacement of East Asian RMG imports into the U.S. and Canada. To the extent these exports by the more efficient East Asian producers are then diverted to the European Community, they may tend to displace Bangladesh's RMG exports into Europe". In the US market another challenge will come from Mexican apparel industry where it has zero tariff access because of NAFTA. Mexico's share in US clothing imports increased by over 200\% in the period 1993-98. Extension of NAFTA membership to the other Latin American and Caribbean countries may aggravate the situation further. 
Public-Private Partnerships in Bangladesh Garment Industries: From the Perspective of Performance Improvement and Sustainability

It goes without saying that, competition is not likely to remain just in the export space; the industry is likely to face competition from cheaper imports as well. It can be as big as readymade garments. But a few exporters are damaging the potential in the international markets. Some exporters quoted the price of their low-end products as high as $\$ 12.5$ per kilogram -- for the purpose of securing government incentives. But these vested people offer $\$ 3$ per kilogram to foreign buyers who visit Bangladesh instead of the minimum \$3.5 per kilogram, he added. "Foreign buyers get puzzled to see a big difference in price between the local exporters. But what is heartening for the exporters is that the central bank and the Anti-Corruption Commission are looking into the issue of incentive misuse by certain firms, added the industry insiders. This consequence likely to affects the domestic industry and may lead to increased consolidation. Ecological and social awareness is likely to result in increased pressure on the industry to follow the international labor and environment laws; this has resulted in increased pressure on companies to limit sourcing from countries/companies known to have such practices as well.

Bangladeshi industry needs to prepare for the fall out of such issues by improving its working practices. Interregional trade blocs pay a significant role in the global terry towel industry with countries enjoying concessional tariffs by virtues of being member of such blocs/alliances. The largest threat to the textile industry is present gas crisis at every region of our country. The sudden price hike of cotton and yarn in the domestic market may push Bangladesh to a very awkward situation to devastate the business. The type of labor and political anarchies of the recent days if prevails in the future, Bangladesh may lose the business in the way Sri Lanka has lost. Growing transnational terrorism, or its false/amplified propaganda, is also a big threat. As a result no new terry industry has permitted for erection from the government.

\section{PPP strategy and modes for Bangladesh garment industry}

\subsection{Strategy position}

Based on the above SWOT analysis, we can know that there is a series of cooperation strategies for private and public companies in Bangladesh Garment industry. The best strategy is the combination of Strength-Opportunity (SSO), which means to share strength of both partners by making use of opportunities in operating environment. The second best strategy is the combination of SW under opportunities, including Strength-Weakness-Opportunity (SWO) and Weakness-Strength-Opportunity (WSO). In the following sections, more details of the best and second best PPP strategies and the relevantimplement modes will be discussed.

\subsection{The best cooperation strategy (SSO) and the implement modes}

Strength-Strength-Opportunity (SSO) strategy aims to create new values for both the private company and the public company by making efficiently use of their advantageous resources or capabilities simultaneously. This type of cooperation is beneficial for both sectors and the whole industry. Since both the private and the public sector can improve its performance, they have motivations to start and maintain such partnerships. It means, the SSO cooperation strategy has the most potential to be applied. 
Tonusree Majumdar

According to relevant information in the SWOT section, the strength of private and public companies in Bangladesh Garment industry could be summarized as following table 1 .

Table 1: Summary of strength of private and public company

\begin{tabular}{|c|c|}
\hline Strength of private company & Strength of public company \\
\hline $\begin{array}{l}\text { 1. Government supports (subsidies, } \\
\text { guarantees) }\end{array}$ & $\begin{array}{l}\text { 1. Financial support (high capital and low } \\
\operatorname{tax} \text { ) }\end{array}$ \\
\hline 2. Powerful incentives to perform & 2. Easier long-term planning \\
\hline 3. The employee is more creative & $\begin{array}{l}\text { 3. More cooperation relationships and } \\
\text { experience }\end{array}$ \\
\hline $\begin{array}{l}\text { 4. Better performance (sufficient cash } \\
\text { flows) }\end{array}$ & 4. More cooperation (experience) \\
\hline 5. Cheaper labor cost & 5. Promote, advanced city image \\
\hline $\begin{array}{l}\text { 6. Lower production cost by using gas as } \\
\text { fuel }\end{array}$ & $\begin{array}{l}\text { 6.Extra production capacity or } \\
\text { underutilized assets }\end{array}$ \\
\hline $\begin{array}{l}\text { 7. Wider international market because of the } \\
\text { membership of GSP in } 2017\end{array}$ & \\
\hline
\end{tabular}

According to the practical situation in Bangladesh garment industry, there is one important and possible means for private and public companies to combine their strength and create more values. That is to execute rational division of labor by transferring the production tasks to private company and leaving the marketing function to public companies. Obviously, comparing with public company, the private companies are more capable to reach low cost because of their cheaper labor cost and cheaper production cost. Therefore, it will be very beneficial for cost declining if the private companies could take up the production work. Similarly, public companies could expand market effectively with their high image. Therefore, public companies should take the responsibility of international marketing, so as to get more orders from the Chinese, American or European market by taking advantage of private firms' GSP membership.

\subsection{The second best cooperation strategy and the implement modes}

Second best strategies include two main types, to combine the strength of private company and the weakness of public company, and to combine the weakness of private company and the strength of public company. In nature, we could name such cooperation as complementary cooperation. Since one of the two partners will enjoy more benefits from such cooperation by overcoming its weakness, these strategies could not be self-enforcing comparing to the first best strategy SSO. Encouragement from outside (e.g. the government) or strategic long-term planning of players is critical forces to stimulate this type of complementary cooperation.

Table 2:Summary of strength and weakness of private and public company 
Public-Private Partnerships in Bangladesh Garment Industries: From the Perspective of Performance Improvement and Sustainability

\begin{tabular}{|c|c|}
\hline Strength of public company & Weakness of private company \\
\hline $\begin{array}{l}\text { 1. Financial support (high capital and } \\
\text { low tax) }\end{array}$ & 1. Low reputation \\
\hline 2. Easier long-term planning & 2. Lack of capital \\
\hline $\begin{array}{l}\text { 3. More cooperation relationships and } \\
\text { experience }\end{array}$ & 3. Bank interest rate is still high \\
\hline 4. More cooperation (experience) & $\begin{array}{l}\text { 4. Cost of doing business is high because of } \\
\text { under table money }\end{array}$ \\
\hline 5. Promote, advanced city image & 5. Custom fee \\
\hline $\begin{array}{l}\text { 6. Extra production capacity or } \\
\text { underutilized assets }\end{array}$ & \\
\hline
\end{tabular}

Table 3: Summary of weakness and strength of private and public company

\begin{tabular}{|c|c|}
\hline Weakness of public company & Strength of private company \\
\hline 1.Loss of influence on investment & $\begin{array}{l}\text { 1. Government supports } \\
\text { (subsidies, guarantees) }\end{array}$ \\
\hline 2. Low productions, higher price & 2. Powerful incentives to perform \\
\hline 3.Financial risk (termination fees) & 3. The employee is more creative \\
\hline $\begin{array}{l}\text { 4. Lacking in number of skilled manpower } \\
\text { which is some cases delays works }\end{array}$ & 4. Better performance (sufficient cash flows) \\
\hline 5. Leaderships and management issues. & 5. Cheaper labor cost \\
\hline \multirow[t]{2}{*}{ 6. Poor infrastructure } & 6. Lower production cost by using gas as fuel \\
\hline & $\begin{array}{l}\text { 7. Wider international market because of the } \\
\text { membership of GSP in } 2017\end{array}$ \\
\hline
\end{tabular}

According to the practical situation in Bangladesh garment industry (see table 2 and 3 ), we can put forward the following three easy-implement means, not all the possible means, for private and public companies to implement complementary cooperation. And, these three types of cooperation could be carried out through several kinds of formations 


\section{Tonusree Majumdar}

(e.g. cooperation contracts, equity strategic alliances, joint ventures or even mergers and acquisition). We discuss the collaboration details as follows.

Firstly, in order to help private companies overcome their weakness of low reputation; the private companies could form various kinds of strategic alliances with public companies, especially with those large public companies who have rather good market image and reputation. Such action could quickly raise the image of new company or low-reputation Company.

Secondly, to help the private company solve capital shortage and high cost of financing, the public companies could share their surplus capital by forming investment partnerships. Both the private and public company could enjoy benefits from such capital resource combination. For the private, monetary problem could be solved and production activities could be expanded to meet the international orders, and finally their profits could be increased significantly. For the public company, they can share private company's increment of profits according to their investment. In this way, a win-win outcome could be realized.

Thirdly, to help the public companies improve their poor infrastructure and increase their production, the private company can share their production lines by developing outsourcing cooperation relationship. It means, the public company could eliminate or abandon some of its poor equipment. And production tasks could be transferred to private companies when orders exceed its left production capacity. In this way, the public company could save a lot of money for production activities in which it is of low efficiency, and the private company's production capacity could be utilized fully. Obviously, such outsourcing cooperation is very beneficial for the two players to save production cost, to increase production efficiency and create more profits finally.

\section{Conclusion and recommendation}

In my concluding remarks I must say that the SWOT analysis of public-private partnership in Bangladesh garments industry can work as a complementary outline to improve the performance of Bangladesh Garments Industry and sustainability .After the strategic analysis of the Readymade Garments industry of Bangladesh, we can find some cooperation strategy which will be very beneficial for the two partner (public and private company) to save production cost, to increase production efficiency and create more profits. Using cooperative strategic factor in public-private partnership for Bangladesh Garments Industry we can find that labor cost and human resource is the main strength of Bangladesh Garments Industry which can improve our garments industries performance potentially.

In recommendation, we must say that,

(1) Bangladesh Garments Industry should look for some strategic plan which can help the industry to create a beneficial field in domestic and internationally.

(2) Opportunities of RMG industry must be converted to strength with the cooperation of public-private companies.

(3) Manufacturers should look for other strategy like value chain competitiveness rather that only price competitiveness. 
Public-Private Partnerships in Bangladesh Garment Industries: From the Perspective of Performance Improvement and Sustainability

(4) The operational mechanisms and procedural guidelines should be worked out immediately. The PPP Policy and Strategy should be specific according to the guidelines.

(5) Conduct policy research and analysis on PPP issues and make recommendations for reform, and craft a PPP roadmap to be adopted by the Government of Bangladesh and the private garments sector.

Rather than trying to do everything equally all at once, it helps to have a sense of priority. Putting the prioritized elements together in a mutually supportive and logical package creates a strategy. The desirable outcome of a SWOT should be a strategic plan to address the challenges.

Thus, by establishing the relationship with public and private sector in Bangladesh Garments Industry, a degree of clarity is possible that helps to make one clear about priorities and the time a policy will take to bring the outcomes.

\section{REFERENCES}

1. R.P.Briones, Public-Private Partnership Approach For Sustainable Development, Greenergy Solut. Inc., 2012.

2. K.A.Mottaleb and T.Sonobe, An inquiry into the rapid growth of the garment industry in Bangladesh, Econ. Dev. Cult. Change, 60(1) (2011) 67-89.

3. M.Quddus and S.Rashid, Entrepreneurs and Economic Development: the remarkable story of garment exports from Bangladesh. University Press, 2000.

4. M.R.Hassan, PPP in Bangladesh: Reality and Prospect, ASA Univ. Rev., vol. 6, 2012.

5. J.A.Gomez-Ibanez and J.R.Meyer, Going private: The international experience with transport privatization. Brookings Institution Press, 1993.

6. A.Conulst, Inc., 'Synthesis of Public-Private Partnerships Projects for Roads, Bridges \& Tunnels From Around the World-1985-2004.,' Public Work. Financ. Westfield, NJ, 2004.

7. L.B.Sagalyn, Public/private development: Lessons from history, research, and practice, J. Am. Plan. Assoc., 73(1) (2007) 7-22.

8. D.Cumming, Government policy towards entrepreneurial finance: Innovation investment funds, J. Bus. Ventur., 22(2) (2007) 193-235.

9. M.M.Kumaraswamy and X.Q.Zhang, Governmental role in BOT-led infrastructure development, Int. J. Proj. Manag., 19(4) (2001) 195-205.

10. Mohammad Abu Bakar Siddiquee, Abul Kashem Mohammad Ayatullah Hosne Asif, Mahbubur Rahman, International Journal of Business and Economics Research, 3(1)(2014) 37-41. doi: 10.11648/j.ijber.20140301.15

11. CPD (2014) 'Technological upgradation, human capital formation, skill development, required for country's RMG prospects'. 20 February. Dhaka: Centre for Policy..http://ppi.worldbank.org/features/sept2006/currentFeatureSept2006.pdf.

12. Huamin Research Center, School of Social Work, Rutgers University China Philanthropy Research Institute, Beijing Normal University Huamin Philanthropy Brochure Series, 2 September 2012. 